\title{
KONTRIBUSI GERRIT CORNELIS BERKOUWER TERHADAP PEMBAHASAN KEBEBASAN MANUSIA
}

\author{
Verawati Halim ${ }^{1}$, Jadi S. Lima ${ }^{2}$ \\ ${ }^{1}$ International Reformed Evangelical Fellowship, Tokyo, Japan \\ ${ }^{2}$ Sekolah Tinggi Teologi Reformed Injili Internasional \\ Korespondensi: faye.des@gmail.com, yadislima@gmail.com
}

\begin{abstract}
ABSTRAK: Diskusi akan kebebasan manusia di akhir abad-20 telah mengalami penyempitan menjadi sebuah pertengkaran mengenai kebebasan kehendak, khusunya antara para penganut Libertarianisme melawan para pengikut Determinisme. Ujung perdebatannya adalah pada otonomi atau heteronomi manusia terhadap kedaulatan Tuhan. Mereka yang ingin menekankan otonomi manusia berusaha untuk menghilangkan segala batasan-batasan yang menghalangi kebebasan manusia. Namun setelah segala batasan-batasan tersebut ditiadakan, muncul pertanyaan-pertanyaan mengenai kuasa-kuasa internal dan eksternal yang mengondisikan hasrat dan keputusan-keputusan manusia. Menurut penulis, para teolog yang membahas permasalahan kebebasan manusia dengan pendekatan "bebas dari" (kebebasan negatif) tidak akan dapat menyentuh esensi kebebasan manusia. Gerrit Cornelis Berkouwer memberikan pembahasan mengenai kebebasan manusia bukan dengan pendekatan "bebas dari" yang pada akhirnya terjatuh menjadi humanisme sekuleristis, tapi melihat arti kebebasan secara alkitabiah, yaitu apa yang dipercayanya sebagai kebebasan yang sejati. Kebebasan ini tidak bergantung pada batasan-batasan baik eksternal maupun internal melainkan merupakan kebebasan eskatologis dimana pada akhirnya kebebasan manusia akan dialami di dalam ketaatan penuh pada Kristus.
\end{abstract}

KATA KUNCI: kebebasan; kehendak bebas; otonomi; heteronomi; otoritas.

ABSTRACT: At the end of the $20^{\text {th }}$ century discussions about human freedom has become discussions about free will. Discussions about this topic 
end up with the polemic between autonomy and heteronomy. The idea of autonomy tries to eliminate all limitations that obstruct human freedom. But after all the limitations have been eliminated, there are some raise questions about internal authority in a person's self that limits him or her. In the opinion of the writer, theologians who approaches the problem of human freedom as a 'freedom from' would never touch the essence of human freedom. Gerrit Cornelis Berkouwer discusses human freedom not with the 'free from' approaches that will lead to a secularistic humanism but tries to look at the meaning of freedom biblically, that is "true freedom." This kind of freedom does not depend on both external nor internal authorities, but rather depend on the hope of eschatological liberation where the believers will be in full obedience to Christ.

KEYWORDS: freedom; free will; autonomy; heteronomy; authority.

Polemik di seputar kebebasan berbicara vs. ujaran kebencian, kebebasan bertindak vs. hidup yang bertanggungjawab, kebebasan 'memilih jenis kelamin' vs. 'menerima keterciptaan' dan sebagainya berakar pada cara memahami kebebasan manusia.

Di alam Modern sekuler seringkali kebebasan manusia diartikan secara sempit sebagai otonomi, yakni terlepas dari segala batasan-batasan yang bukan ditentukan sendiri oleh dirinya maupun alam. Di satu sisi, orang tidak percaya dengan adanya kebebasan yang otonom karena melihat manusia tidak dapat lepas dari batasan-batasan seperti budaya, kebutuhan, bahkan keterbatasan fisik - sementara di sisi lain keterbatasan-keterbatasan ini nyata-nyata tidak harus diterima begitu saja sebab manusia mampu untuk mengubahnya.

Ada dilemma antara Determinisme vs. Libertarianianisme yang menemui kebuntuan. Diperlukan adanya cara berpikir yang secara radikal berbeda untuk dapat keluar dari jebakan dilemma ini. G. C. Berkouwer (1903-1996) menawarkan solusinya dari titik berangkat teologis yang Kristiani. Tulisan ini menelusuri kontribusi Berkouwer dalam usahanya untuk memahami kebebasan manusia dari sudut pandang yang Alkitabiah. Berkouwer menyusun solusinya lewat dialog dengan berbagai pemikiran dalam tradisi Reformed, secara khusus John Calvin dan Herman Bavinck.

\section{Pembacaan Historis G.C. Berkouwer Mengenai Kebebasan Manusia}

Istilah kebebasan telah ada sejak era para Bapa gereja awal. Walaupun para Bapa gereja mula-mula menggunakan istilah kebebasan dalam bahasa 
Yunani dan Latin, ${ }^{1}$ mereka tidak memiliki pengertian kebebasan yang hanya berfokus pada manusia secara otonom. Istilah kebebasan yang dimengerti oleh bapa-bapa gereja merupakan suatu istilah yang digunakan dalam hubungannya dengan Tuhan. ${ }^{2}$ Polemik mengenai kebebasan manusia berakar pada Pelagius yang menyatakan bahwa setelah Kejatuhan, manusia masih memiliki kapasitas untuk memilih yang baik, karena manusia masih melakukan perintah Tuhan yang lain pada saat itu; tanpa kebebasan untuk memilih baik atau jahat maka tidak akan ada doktrin imputasi kesalahan Adam. ${ }^{3}$ Demi mempertahankan faktor tanggung jawab manusia terhadap pilihan tindakan yang dilakukan, Pelagius berpendapat bahwa manusia masih memiliki hati nurani yang suci, sebagai manusia ciptaan Allah. Sementara Pelagius membahas kebebasan formal secara logis, Agustinus mengambil sisi kebebasan sejati secara religius (kuasa untuk melakukan kebaikan). Polemik mengenai kebebasan manusia kemudian berlanjut satu millenium kemudian ketika Erasmus of Rotterdam mengatakan,

by 'free will' [liberum arbitrium] ... we understand a power of the human will by which man may be able to direct himself towards, or turn away from, what leads to eternal salvation. ${ }^{4}$

Martin Luther menolak konsep tentang kebebasan yang diajukan oleh Erasmus. ${ }^{5}$ Polemik antara Martin Luther dan Erasmus menjadi pembahasan mengenai kehendak bebas manusia. Pembahasan ini adalah tentang apakah manusia terbuka atau tidak terbuka terhadap karunia Tuhan dan dapat menerima karunia itu secara "bebas" atau tidak. ${ }^{6}$ Polemik ini bukan lagi mengenai kebebasan manusia melainkan mengenai kehendak bebas. Pembahasan mengenai kehendak bebas hanyalah sebagian kecil dari

Bapa-bapa Yunani: menurut Chrysostom, pilihan dan keputusan adalah milik manusia tapi pilihan dan keputusan ini haruslah untuk menyenangkan Tuhan. Menurut Clement of Alexandria, Adam bukan sempurna tapi hanya diberi kemampuan untuk berbuat baik dan menentukan jalan hidup sendiri adalah natur dari jiwa manusia. Cyril of Jerusalem mengatakan bahwa karunia tersebut memerlukan kemauan untuk percaya seperti sebuah pena yang memerlukan tangan untuk dapat menulis. Gregory Nazianzen memberikan komentarnya pada Roma 9:16, bahwa "sekedar kehendak manusia" tidak lebih penting daripada "menghendaki dan menjalankan." Bapa-bapa Latin: Tertullian mengakui bahwa di samping kebebasan Tuhan yang mahakuasa telah membatasi kebebasan manusia, tapi penjagaan agar kehendak manusia dapat menginginkan hal yang baik merupakan karya Allah. Cyprian setuju bahwa kasih karunia diterima sesuai dengan kapasitas iman yang manusia dapat berikan, tapi segalanya ditentukan oleh kehendak Tuhan. Ambrose melihat bahwa ide kebebasan terletak pada konsep akan ketaatan, ia menekankan karya penebusan yang efisien adalah inisiatif dari Tuhan.

2 Eduard Heimo Hofmeister, "Freedom," The Encyclopedia of Christianity (Grand Rapids, Leiden: Eerdmans; Brill, 1999-2003), 351.

G. C. Berkouwer, Sin, Studies in Dogmatics (Grand Rapids: Eerdmans, 1971), 430.

Hofmeister, "Freedom," 351.

Erasmus dalam bukunya The Freedom Of The Will (1524) yang menuliskan tentang adanya kehendak bebas dan ditanggapi oleh Martin Luther dalam bukunya The Bondage Of The Will (1525), trans. Edward Thomas Vaughan, M. A. (London, 1823).

6 G. C. Berkouwer, Man: The Image of God (Grand Rapids: Eerdmans, 1960), 315. 
kebebasan manusia itu sendiri.

Dalam buku keempat Institutes (IV, 20, 1), John Calvin merujuk kepada 1 Korintus 7:21 dan mengamati bahwa kebebasan spiritual dapat berjalan bersama dengan perhambaan jasmani. Calvin membela kedaulatan Allah atas manusia dan menempatkan kebebasan Allah di atas segala relasi yang sekuler.7 Dalam kalimatnya (Institutes II, 2, 7), "He is a "willing" servant of sin, and his will is fettered with the shackles of sin," Calvin menegaskan penolakannya terhadap pemahaman kebebasan manusia sebagai kebebasan kehendak secara otonom. Calvin bukan mengatakan bahwa kehendak bebas tidak ada. Tapi Berkouwer melihat bahwa yang tidak disetujui oleh Calvin adalah pandangan kehendak bebas yang berdasarkan determinisme. Pandangan kehendak bebas yang berdasarkan determinisme adalah manusia dapat menentukan pilihannya sendiri sebagai manusia yang otonom. ${ }^{8}$ Calvin mengatakan bahwa manusia diciptakan dengan kuasa yang besar untuk memiliki kehendak bebas, tapi karena jatuh dalam dosa maka manusia kehilangan kehendak bebas ini. ${ }^{9}$ Lalu Berkouwer melanjutkan pendapatnya bahwa Calvin membedakan situasi sebelum dan setelah Kejatuhan, yang berarti bahwa sebelum Kejatuhan ada kebebasan dan setelah Kejatuhan kehendak bebas hilang. ${ }^{10}$ Kejatuhan menandai perubahan besar, karena manusia telah kehilangan apa yang dulu pernah ia miliki. ${ }^{11}$

Selain Calvin, pemikiran Immanuel Kant sangat penting dalam pembahasan kebebasan manusia. ${ }^{12}$ Kant memberikan cara berpikir yang baru terhadap kebebasan. ${ }^{13}$ Ia membuka jalan dengan merumuskan antithesis antara pandangan otonomi dan heteronomi. Seperti yang dikatakan oleh Craig G. Bartholomeuw mengenai Immanuel Kant, bahwa prinsip otonomi adalah kemampuan untuk menaati hukum moral yang dibuatnya sendiri dan ini merupakan prinsip moral tertinggi. ${ }^{14}$ Bagi Kant, peran akal budi adalah untuk melakukan sesuatu dengan materi dan usaha manusia. Akal budi adalah suatu elemen yang menolak otoritas eksternal. ${ }^{15}$

Sedangkan prinsip heteronomi mengakui bahwa keharusan tindakan dilakukan sebagai sesuatu yang semata-mata berasal dari berbagai hal

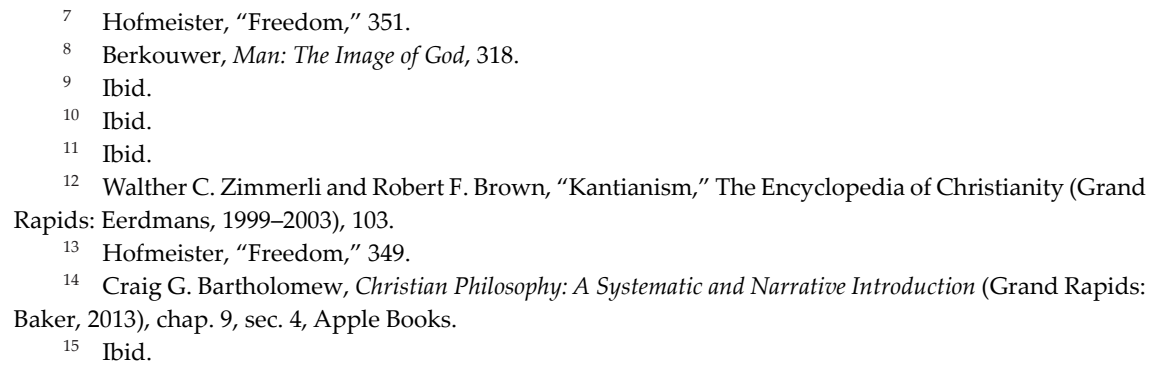


lain di luar kehendak manusia sendiri. ${ }^{16}$ Yang dimaksudkan oleh Kant dengan heteronomi adalah penyebab-penyebab yang berasal dari realitas eksternal. ${ }^{17}$ Penyebab-penyebab dan hukum-hukum inilah yang menjadi batasan-batasan sehingga manusia tidak mungkin bebas murni di dalam dunia realitas eksternal. Di sini Kant menghadapkan prinsip otonomi, yang merupakan hasil dari akal murni sebagai kewajiban, dan prinsip heteronomi, yang dipengaruhi oleh kondisi-kondisi luar untuk mencapai suatu tujuan tertentu. ${ }^{18}$

Pemikiran Immanuel Kant mengenai otonomi dan heteronomi memberikan dampak besar terhadap konsep kebebasan manusia di zaman modern. Kesadaran akan kebebasan terus berkembang bukan hanya pada lingkaran praktisi tapi juga pada lingkaran intelektual yang mengokohkan adanya kebebasan manusia yang merupakan perkembangan dari pemikiran Immanuel Kant mengenai otonomi dan heteronomi. ${ }^{19}$ Antithesis prinsip otonomi dan prinsip heteronomi dari Immanuel Kant kemudian hari berkembang menjadi pandangan otonomi yang percaya bahwa manusia memiliki kebebasan dan pandangan heteronomi yang melihat bahwa manusia selalu memiliki batasan-batasan dalam menentukan aksinya.

Pandangan otonomi yang berkembang dalam era paska Kant adalah penentuan yang keluar dari diri sendiri sepenuhnya dan tanpa paksaan dari kuasa eksternal. ${ }^{20}$ Pandangan otonomi percaya akan adanya kebebasan yang ideal dan mengandalkan natur manusia yang dapat membuat penentuan sendiri terlepas dari kuasa apapun. ${ }^{21}$ Pandangan otonomi melihat manusia sebagai subyek absolut yang menjadi hukum itu sendiri. ${ }^{22}$ Subyek yang absolut memiliki kebebasan diri sendiri yang murni.

Dalam pembahasan mengenai kebebasan manusia, kebanyakan teolog berfokus pada pertanyaan tentang manusia yang merasa perlu untuk memiliki pandangan otonomi. ${ }^{23}$ Pandangan otonomi teologis mengaitkan kebebasan dengan tanggung jawab manusia, jika manusia dengan bebas

16 Immanuel Kant, Kant's Critique of Practical Reason And Other Works On The Theory Of Ethics, translated by: Thomas Kingsmill Abbott (Dublin: Ponsonby and Gibbs, 1909), 63.

17 Ibid.

18 Ibid., 64.

19 Berkouwer, Man: The Image of God, 312.

20 Ernst Feil, "Autonomy," The Encyclopedia of Christianity (Grand Rapids; Leiden: Eerdmans; Brill, 1999-2003), 174.

21 F. W. J. Schelling dalam esainya Human Freedom (1809) yang mengatakan bahwa kebebasan adalah potensi untuk kebaikan maupun kejahatan; J. F. Fries mengatakan bahwa otonomi sebagai dorongan, pilihan, dan tanpa pertimbangan; G. W. F. Hegel berbicara tentang otonomi mutlak; H. Marcuse mengatakan tentang otonomi sebagai penentuan diri secara total tanpa adanya kuasa atau penentuan dari luar; dll.

22 Berkouwer, Man: The Image of God, 327.

23 Ibid., 316. The problem with which the Reformation was concerned was not first of all a psychological or anthropological problem, and still less was it taught that man did not will or act or choose: attention was directed to man as active and willing! 
memiliki kehendak untuk melakukan sesuatu maka ada tanggung jawab manusia di dalam aksi tersebut. ${ }^{24}$ Tetapi masalahnya manusia berdosa dengan kehendak yang diperbudak tidak mungkin dapat dengan bebas menentukan suatu aksi. Pandangan mengenai kebebasan manusia ini telah mengalami sekularisasi dan akhirnya bergeser dari pengertian kebebasan yang tertulis dalam alkitab menjadi pandangan mengenai kehendak yang bebas-otonom. ${ }^{25}$ Pembahasan tentang kehendak bebas hanyalah sebagian kecil dari subyek studi tentang kebebasan manusia itu sendiri secara umum. Berkouwer mengkritik pandangan otonomi sebagai naif karena berasumsi bahwa manusia dapat dengan bebas menentukan tindakannya terlepas dari kuasa apapun seakan-akan kehendak dari manusia tersebut bukanlah kehendak dari seorang manusia yang telah jatuh ke dalam dosa, suatu kehendak yang tidak diperbudak oleh dosa. ${ }^{26}$

Kebalikan dari pandangan otonomi, pandangan heteronomi membahas bahwa manusia tidak dapat bebas karena adanya faktor-faktor eksternal yang mempengaruhinya dalam menentukan aksinya. Berkouwer melihat bahwa pandangan otonomi tidak memperhitungkan adanya faktor-faktor selain faktor eksternal. ${ }^{27}$ Pandangan heteronomi mempertanyakan apakah manusia bebas pada sejatinya yaitu faktor-faktor yang ada di dalam dirinya sendiri atau oleh dirinya sendiri. ${ }^{28}$ Tanpa adanya otoritas eksternal pun, manusia harus menghadapi otoritas internal yang ada di dalam dirinya. Otoritas-otoritas internal seperti tradisi, kebudayaan dan konsep-konsep bersifat menentukan dan dapat membatasi kebebasan manusia sama seperti otoritas eksternal yang membatasi kebebasan manusia. Otoritas internal ini sama seperti adanya dominasi yang bersifat heteronomi dalam diri sendiri. ${ }^{29}$ Otoritas internal yang membatasi kebebasan inilah yang menjadi kritik-kritik dari para pemikir heteronomi kepada pandangan otonomi yang berusaha mencapai kebebasan ideal. ${ }^{30}$

Polemik antara pandangan otonomi dan heteronomi berfokus pada ada atau tidaknya otoritas-otoritas yang membatasi manusia dalam menentukan tindakannya. Pembahasan mengenai kebebasan manusia ini tidak

24 Linda Trinkaus Zagzebski, The Dilemma of Freedom and Foreknowledge (New York: Oxford University Press, 1991), 155, http://www.myilibrary.com?id=45291\&ref=toc (diakses 6 September 2016).

25 Erwin Fahlbusch, The Encyclopedia of Christianity (Grand Rapids, Mich.: Wm. B. Eerdmans, 19992008), 352.

26 Berkouwer, Man: The Image of God, 318.

27 Ibid., 311.

28 Ibid., 311.

29 Colin E. Gunton, ed., God and Freedom: Essays in Historical and Systematic Theology (Edinburgh: T \& T Clark, 1995), 58-59.

30 Jean-Jacques Rousseau menyebutnya sebagai tindakan non-moral; Jacques Derrida dalam karyanya Derrida And Negative Theology, mengatakan bahwa otonomi tidak mungkin ada; dll. 
dapat dilepaskan dari pembahasan akan kehendak bebas, seperti diskusi zaman reformasi. ${ }^{31}$

\section{Solusi Berkouwer dari Pandangan Reformed terhadap Polemik Kebebasan Manusia}

Dalam melihat polemik antara pandangan otonomi dan heteronomi, Berkouwer mengambil ide dari sejumlah pandangan para teolog dari tradisi Reformed, terutama dari Calvin dan Bavinck. Para reformator menentang adanya kebebasan kehendak sebagai proklamasi mengenai krusialitas anugerah ilahi. ${ }^{32}$ Para reformator tidak setuju bahwa kebebasan adalah struktur esensial dari natur manusia karena kebebasan telah hilang karena kuasa dosa. Kontroversi antara Luther dan Erasmus adalah tentang apakah manusia dapat menerima anugerah ilahi dengan bebas atau tidak. ${ }^{33}$ Luther (dan selanjutnya diteruskan oleh Calvin) menyangkal apa yang disebut kehendak bebas tapi bagi para teolog Katolik, hal ini dilihat sebagai hal yang tidak sejalan dengan struktur antropologis kebebasan manusia. Menurut Berkouwer, Reformasi bukan tidak setuju dengan adanya kebebasan manusia. ${ }^{34}$ Melainkan pandangan mengenai kehendak bebas yang dipermasalahkan oleh para Reformator. Calvin sebagai salah seorang reformator tidak menyetujui sikap para bapa gereja yang terlalu banyak membahas pertanyaan tentang kehendak bebas karena dinilainya bahwa pemikiran para bapa gereja mengenai kebebasan tidak lepas dari sudut pandang determinisme dan jauh dari pengajaran yang ditulis di Kitab Suci. ${ }^{35}$ Berkouwer melihat Calvin menyimpulkan bahwa para bapa gereja terlalu dipengaruhi cara berpikir para filsuf terhadap permasalahan ini. ${ }^{36}$ Tapi Calvin membahas kehendak bebas dalam sudut pandang dosa, bahwa manusia melakukan dosa dengan kehendaknya tanpa desakan. Berkouwer melihat ketidaksetujuan Calvin terhadap penggunaan kata "kehendak bebas" karena penggunaannya yang tidak sesuai dengan pengajaran dalam Alkitab. ${ }^{37}$ Dalam pembahasan kehendak bebas, Calvin menyebut manusia sebagai willing servant of sin. Kehendak bebas yang sebelum Kejatuhan dimiliki oleh manusia telah hilang, manusia merusaknya. ${ }^{38}$

31 Berkouwer, Man: The Image of God, 310-312.

32 Ibid., 314.

33 Ibid.

34 Ibid., 316.

35 Ibid., 318.

36 Ibid.

37 Ibid., 319.

38 Dalam poin ini lihat juga Canons of Dordt, III, IV, Rejection of Errors. Di sini kehendak bebas ditolak dan peninggian kekuatan kehendak bebas (III, IV, III), merujuk pada hati yang penuh dosa. Cf. the Confessio Scotiana, art. 2, on the original libertas arbitrii (Müller, Die Bekenntnisschriften der Reformierten Kirche, 250); 
Kata "willing servant of sin" yang digunakan oleh Calvin (Institutes II, $2,7)$ menunjukkan pandangannya terhadap permasalahan kehendak bebas. Calvin tidak keberatan jika istilah 'kehendak bebas' dipakai untuk mengatakan bahwa manusia berdosa dengan keinginannya sendiri dan tidak ada desakan sama sekali. Dalam buku Institutes, Calvin mengatakan bahwa terminologi ini harus digunakan dengan sangat hati-hati dan sebaiknya tidak perlu digunakan sama sekali (Institutes II, 2, 8). Karena Calvin melihat bahwa penggunaan istilah kehendak bebas mengandung arti otonomi manusia yaitu manusia dapat dengan bebas, tanpa pengaruh kuasa ataupun desakan dari luar untuk menentukan jalannya. Penggunaan istilah kehendak bebas ini tidak melihat dari sudut pandang dosa dan bahwa keinginan manusia telah dipengaruhi oleh dosa. Jadi Berkouwer melihat bahwa Calvin membahas permasalahan kehendak bebas ini dari sudut pandang historis dan religius. Karena itu Calvin melihat ironi antara manusia yang menyerukan kehendak bebas padahal mereka sebenarnya adalah budak dosa (Institutes II, 2, 8). Calvin menyimpulkan relasi antara kebebasan manusia dengan dosa adalah manusia bebas sebelum jatuh dalam dosa dan kehilangan kebebasan ini karena dosa. ${ }^{39}$ Manusia berdosa tidak dapat meninggalkan kehendaknya dengan kuasanya sendiri. Ini adalah keinginan yang telah diperbudak, servum arbitrium. ${ }^{40}$

Kesimpulan dari pandangan Reformasi tentang kebebasan manusia adalah sebelum Kejatuhan ada kebebasan, setelah Kejatuhan adalah perbudakan. ${ }^{41}$ Pandangan Reformasi ini tidak jatuh pada pandangan otonomi ataupun heteronomi yang berdasarkan determinisme. Pandangan ini adalah pandangan yang Alkitabiah mengenai kebebasan. Pandangan yang menyangkal adanya kebebasan teoretis yang formal ini, yaitu ada dan tidaknya kebebasan sebelum Kejatuhan dan sesudah Kejatuhan, akan sampai pada kesimpulan akan tidak adanya kebebasan atau sebaliknya akan sampai kepada ide bahwa kebebasan berasal dari otonomi manusia dan pilihan

Confessio Helvetica Posterior, art. IX, kehendak itu telah menjadi diperbudak, "voluntas vero ex libera facta est voluntas serva" (ibid., 179); cf. "servit peccato non nolens, sed volens. Etenim voluntas, non noluntas dicitur" (ibid.); dikutip dari Berkouwer, Man: The Image of God, 318.

39 Berkouwer, Man: The Image of God, 319.

40 Poin ini dapat dipertajam dengan mengatakan bahwa kita tidak berurusan dengan determinisme tapi dengan tuduhan dari nabi Yeremia: “Dapatkah orang Etiopia mengganti kulitnya atau macan tutul mengubah belangnya? Masakan kamu dapat berbuat baik, hai orang-orang yang membiasakan diri berbuat jahat?" (Yeremia 13:23). Cf. Aalders, Commentaar, ad loc. Ia mengatakan bahwa teks ini sering dikutip dalam hubungannya dengan natur manusia yang sudah terkorupsi tapi salahnya, karena ia berhadapan dengan hati yang dikeraskan melalui hidup dalam dosa yang berkelanjutan. Tapi hal ini tidak mengubah kenyataan bahwa ketidakmungkinan yang dibicarakan di sini adalah dalam hubungannya dengan situasi yang telah ada di mana manusia tidak memiliki kekuatan untuk bergerak. Dikutip dari Berkouwer, Man: The Image of God, 321.

41 Berkouwer, Man: The Image of God, 319. 
spontannya. Pandangan yang menyangkal adanya kebebasan teoretis yang formal ini akan menjauhkan orang dari pemahaman kebebasan manusia yang Alkitabiah. Dan pandangan mengenai kebebasan manusia yang Alkitabiah akan sampai pada konsep tentang hidup yang dipulihkan lewat anugerah Tuhan yang digambarkan sebagai hidup yang bebas. Kebebasan yang digambarkan dalam Alkitab bukanlah kebebasan yang otonom dan spontan melainkan suatu kebebasan yang teratur dan terhormat. Kebebasan yang dimaksud adalah manusia yang bebas itu tunduk kepada Tuhan. Kebebasan dan ketundukan kepada Tuhan tidak bertentangan dalam hidup kekristenan. ${ }^{42}$

Mengenai pandangan Bavinck, Berkouwer berbicara tentang pembedaan yang dilakukan oleh Bavinck antara broad sense of humanity dan narrow sense of humanity..$^{43}$ Dalam istilah broad sense of humanity manusia tidak kehilangan esensinya karena tidak tersentuh oleh dosa. Dalam broad sense manusia masih manusia, tapi kerusakan esensi karena dosa terjadi dalam narrow sense of humanity yang berarti bahwa karena Kejatuhan manusia telah kehilangan persekutuan dengan Allah. Berkouwer melihat bahwa pembedaan antropologi semacam ini ${ }^{44}$ akan berujung menjadi penjelasan dan analisa tentang manusia secara netral. Sedangkan Alkitab tidak pernah memberikan penjelasan tentang manusia secara ontologis dan netral selain manusia dalam hubungannya dengan Tuhan. ${ }^{45}$ Berkouwer yang melihat bahwa manusia tidak dapat dijelaskan terlepas dari relasinya dengan Tuhan menolak segala pendekatan metafisik yang mengakibatkan dikotomi dan struktur-struktur ontologis manusia seperti pendekatan dikotomi tubuh dan jiwa dan trikotomi tubuh, jiwa, dan roh. ${ }^{46}$

Berkouwer mengutip pemikiran dari Dooyeweerd,

The heart is not a part of man, but his full "self," or, as he says, "our egoicity as the radical unity of our existence," "the religious center of our existence," which should not be confused with "any one of the modal aspects of the temporal horizon." ${ }^{47}$

Mengenai konsep Dooyewerd tentang "hati," Berkouwer menjelaskan bahwa "hati" yang dimaksudkan oleh Dooyewerd bukanlah masalah fungsi

42 Ibid., 320.

43 Bdk. Berkouwer, Man: The Image of God, 41. Berkouwer melihat pembedaan ini sama dengan pembedaan yang dilakukan oleh A. Kuyper, Jr. dengan istilah imago essentialis dan imago existentialis.

44 Ibid., 40, 41, 43, 61f.

45 Antropologis yang dimaksud disini bukanlah bidang antropologi secara partikular melainkan suatu cara penjelasan ontologis mengenai manusia yang berusaha menjelaskan struktur manusia yang 'self-sufficient dan tertutup' terlepas dari relasinya dengan Allah.

46 Berkouwer, Man: The Image of God, 54.

47 Ibid., 257. 
hati, tapi berarti bahwa keutuhan seseorang dalam segala aspek keberadaannya. ${ }^{48}$ Berkouwer melanjutkan penjelasannya dengan mengatakan bahwa terminologi "hati" yang dipakai oleh Dooyeweerd merupakan keseluruhan diri seorang manusia dan bukanlah hanya satu bagian dari diri manusia tersebut. Karena itu konsep Dooyewerd tentang hati bukanlah dualistik. ${ }^{49}$ Berkouwer menjelaskan bahwa hati yang dimaksud Dooyeweerd tersebut

Not something which should be placed outside its functions, as a new substance which then is joined to the body's function-complex and which can be separated from it at death. The heart is much more man himself in all his functions..$^{50}$

Berkouwer melihat pandangan Dooyeweerd bukan pendekatan ontologis yang mencoba menjelaskan esensi manusia secara netral atau tertutup dari relasinya dengan Tuhan, "[n]amely that we cannot view man's essence in itself and then place it in relation to God." ${ }^{51}$ Pendekatan yang digunakan oleh Dooyeweerd adalah pendekatan yang lain, yaitu relasi adalah esensi. Relasi bukanlah sesuatu yang lebih tinggi yang kemudian ditempelkan kepada esensi, ataupun sebaliknya. ${ }^{52}$

Berkouwer mengatakan bahwa manusia tidak dapat didefinisikan secara mandiri dalam dirinya sendiri (ding an sich) dan terpisah dari relasinya dengan Tuhan. ${ }^{53}$ Pandangan Berkouwer terhadap relasi manusia dengan Tuhan adalah relasi tersebut merupakan realita yang spesial. Dia juga menegaskan bahwa tidak satupun dari segenap ciptaan, segala yang ada, terlepas dari relasinya dengan Tuhan.

Berkouwer juga melihat mengambil definisi tentang manusia dari Belgic Confession tentang manusia. ${ }^{54}$ Article XIV dari Belgic Confession mengatakan bahwa

We believe that God created man out of the dust of the earth, and made and formed him after His own image and likeness, good, righteous, and holy, capable in all things to will agreeably to the will of God.

Manusia diciptakan dalam keadaan "baik, benar, dan kudus" dan "mampu." Tetapi dalam tulisan asli pengakuan ini, kata "baik, benar, dan kudus" ini diikuti oleh kata "sepenuhnya sempurna dalam segala hal." Kata "sepenuhnya sempurna" kemudian diganti dengan "mampu

\footnotetext{
Ibid., 223.

Ibid.

Ibid., 258.

Ibid., 259.

Ibid.

Ibid., 195-196.

Ibid., 334.
} 
membuat sejalan..."55 Bavinck menyadari perubahan ini. Berkouwer mengatakan bahwa Bavinck melihat alasan perubahan ini adalah mereka tahu bahwa manusia pertama belum mencapai kondisi tertinggi. ${ }^{56}$ Karena itu kata "sepenuhnya sempurna dalam segala hal" dinilai tidak sesuai. Tapi mereka tetap menegaskan kebaikan asali manusia seperti tertulis: "baik, benar, dan kudus." Dalam Heidelberg Catechism, Lord's Day 3, Q/A \#6 ditulis "Tuhan menciptakan manusia baik...diciptakan dalam kebenaran sejati dan kekudusan." ${ }^{57}$ Dari dua pengakuan ini Berkouwer melihat bahwa Tuhan tidak menciptakan manusia dengan adanya kemungkinan memilih antara dua pilihan atau dalam kondisi netral karena Tuhan mencintai kebebasan, melainkan Tuhan menciptakan manusia dalam kebenaran dan kekudusan. ${ }^{58}$ Dengan mengatakan kebebasan adalah kemungkinan memilih antara dua pilihan berarti kejatuhan manusia ke dalam dosa adalah implikasi dari kebebasan yang diberikan oleh Tuhan. Pemikiran seperti ini berarti mengatakan bahwa Kejatuhan adalah hasil dari kebebasan manusia. Kebebasan manusia tidak seharusnya dilihat dalam kemungkinan untuk memilih kejahatan. Kejatuhan bukanlah pilihan yang disediakan oleh Tuhan sejajar dengan pilihan untuk manusia sejalan dengan kehendak Tuhan. Melainkan manusia diciptakan dalam kondisi baik, benar, dan kudus. Dengan demikian, kebebasan manusia dan Kejatuhan tidak memiliki relasi sebagai kemungkinan dan realisasi. Tuhan tidak memberikan kebebasan kepada manusia agar mereka melawan kehendak-Nya. Kebebasan yang terkait dengan perintah larangan yang Tuhan berikan kepada Adam disebut kebebasan formal. Kebebasan ketika manusia diperhadapkan pada pilihan sebelum Kejatuhan. Kebebasan formal bukanlah kebebasan sejati dalam artinya yang paling penuh. Berkouwer melihat bahwa kebebasan formal ini akan menimbulkan makna ganda jika memang Adam bebas ketika diperhadapkan pada pilihan untuk berdosa atau tidak berdosa. Pandangan ini akan berujung pada pertanyaan mengenai asal muasal dosa yang digambarkan sebagai kebebasan manusia ketika diperhadapkan pada pilihan untuk berdosa atau

55 Ibid.

56 Ibid.

57 Ibid., 335.

58 Bavinck, op. cit., II, 534-535. Sangat mengejutkan, dalam konteks ini, Bavinck bicara tentang posse stare dan posse non errare, peccare, mori dan kemudian berbicara mengenai kemungkinan berdosa dan mati yang "forms no part, no piece, no content of the image of God, but was its boundary, the limit, the circumference." Bavinck merujuk pada Wendelinus (dikutip oleh Heppe, Dogmatik, 181) yang mengatakan bahwa sebelum Kejatuhan ada kemampuan untuk tidak berdosa (posse non peccare), tapi kemampuan untuk berdosa tidak ada dalam gambar Allah. Dapat kita lihat di sini bahwa pergumulan dengan konsep kebebasan juga sama terjadi pada Bavinck. Gambar Allah yang utuh akan tampak pada kemampuan untuk tidak berdosa. Gambar Allah akan sempurna dan kemungkinan untuk berdosa dan mati akan dikalahkan dan dihilangkan; dikutip dalam Berkouwer, Man: The Image of God, 335. 
untuk tidak berdosa. ${ }^{59}$ Menurut Berkouwer, pandangan seperti ini akan jatuh kepada pemikiran yang tidak alkitabiah seperti telah dijelaskannya di atas. Kitab Kejadian tidak mengatakan bahwa manusia ditempatkan dalam dua pilihan dan kondisi yang netral. ${ }^{60}$

Semua pohon dalam taman ini boleh kau makan buahnya dengan bebas, tetapi pohon pengetahuan tentang yang baik dan yang jahat itu, janganlah kau makan buahnya, sebab pada hari engkau memakannya, pastilah engkau mati. (Kejadian 2:16-17)

Yang diberikan oleh Tuhan kepada manusia bukanlah pilihan melainkan perintah. Perintah ini tidak memberikan kebebasan kepada manusia untuk memilih jalannya sendiri sesuai dengan kehendaknya. Perintah ini menunjukkan hanya satu jalan kepada manusia untuk dijalaninya. Dalam Belgic Confession (Art. XIV) disebutkan, "For the commandment of life, which he had received, he transgressed...." Perintah yang diberikan oleh Tuhan kepada manusia adalah perintah untuk hidup. Jalan yang lainnya tersebut tidak diletakkan sejajar dengan perintah akan kehidupan melainkan ditempatkan di bawah ancaman penghakiman akan kematian. Kemudian perintah untuk hidup ini diterjemahkan dari cara pandang yang berbeda oleh ular:

Sekali-kali kamu tidak akan mati, tetapi Allah mengetahui, bahwa pada waktu kamu memakannya matamu akan terbuka, dan kamu akan menjadi seperti Allah, tahu tentang yang baik dan yang jahat. (Kejadian 3:4-5)

Berkouwer melihat bahwa karena cara pandang inilah muncul pandangan mengenai kebebasan yang diartikan sebagai manusia yang memiliki kehendak bebas diperhadapkan kepada dua pilihan yang sejajar. ${ }^{61}$ Arti kebebasan menjadi bergeser kepada pemikiran yang tidak alkitabiah yaitu kemungkinan diantara dua pilihan. Tapi apa yang ditulis dalam Kitab Kejadian adalah perintah untuk hidup yang tidak meninggalkan kepada manusia pilihan apapun untuk memilih diantara dua jalan, tapi lebih kepada menunjukkan kepadanya penekanan kepada satu jalan yaitu jalan kepada kebebasan, jalan kepada ketaatan. ${ }^{62}$ Kebebasan yang dimaksud adalah kebebasan yang sempurna yaitu kebebasan yang tercapai dalam persekutuan dengan Anak. Kebebasan ini bukan kemungkinan tapi ia adalah kenyataan. Kebebasan yang dimaksud oleh Berkouwer adalah ketaatan sepenuhnya kepada perintah Tuhan. Suatu keadaan manusia yang bebas untuk tunduk dan beribadah kepada Tuhan. Kebebasan ini adalah keadaan

\footnotetext{
Ibid., 332

Ibid., 346.

Ibid.

Ibid.
} 
manusia yang tidak terikat oleh kuasa dosa tapi bebas sebagai ciptaan Tuhan. Suatu keadaan bebas yang eskatologis yang dimiliki melalui iman dan akan menjadi sempurna dalam persekutuan dengan Kristus. ${ }^{63}$ Kebebasan ini disebut kebebasan sejati. Kebebasan ini bukanlah kebebasan manusia yang menjadi polemik antara pandangan otonomi dan heteronomi. Karena baik pandangan otonomi dan heteronomi membahas dilema kebebasan yang artinya sudah bergeser dari arti kebebasan yang alkitabiah. Kebebasan manusia menurut pandangan Berkouwer adalah kebebasan manusia yang sesuai dengan apa yang dinyatakan oleh Alkitab, bukan masalah kehendak bebas, melainkan keadaan manusia yang tidak terikat apapun untuk dapat taat sepenuhnya kepada Allah. Kebaikan dalam manusia dan kebebasannya ada sebelum Kejatuhan. Kebebasan manusia hanya ada dalam persekutuannya dengan Tuhan. ${ }^{64}$ Sejak Kejatuhan kebebasan manusia hilang, tetapi orang percaya akan mendapatkan lagi kebebasan itu secara sempurna dalam persekutuan dengan Tuhan. Kebebasan yang sempurna ini adalah kebebasan yang akan tercapai secara eskatologis.

\section{Solusi Berkouwer sebagai Kontribusi Orisinil terhadap Polemik Kebebasan Manusia}

Selain dari beberapa pandangan Reformed yang lain, analisa Berkouwer terhadap polemik pembahasan kebebasan manusia dipengaruhi oleh pemikiran orisinilnya. Konsep kebebasan manusia yang diperkenalkan oleh Berkouwer adalah konsep kebebasan manusia yang sejati, bukan konsep kebebasan yang telah bergeser menjadi pembahasan mengenai kehendak bebas. Berkouwer mencoba untuk kembali merujuk pada arti kebebasan yang alkitabiah sebagai manusia dalam relasinya dengan Tuhan yang tidak disimpangkan oleh pembahasan-pembahasan filsafat sekuler modern. Kebebasan ini bersifat eskatologis. Kebebasan yang eskatologis adalah kondisi manusia yang dapat dengan bebas tunduk sepenuhnya pada Penciptanya.

Pandangan Berkouwer mengenai kebebasan manusia berkaitan erat dengan pandangannya mengenai relasi antara Tuhan yang adalah Pencipta dan manusia yang adalah ciptaan. Berkouwer menegaskan bahwa manusia tidak dapat dijelaskan terlepas dari relasinya dengan Penciptanya karena ciptaan adalah satu keutuhan dalam relasinya dengan Tuhan. ${ }^{65}$ Berkouwer menolak segala usaha yang mengaburkan perbedaan antara Pencipta dan

\footnotetext{
63 Ibid., 332.

64 Berkouwer, Man: The Image of God, 334.

65 Ibid., 194. Pandangan Berkouwer tentang manusia tidak dapat dijelaskan dengan struktur-struktur ontologis yang terpisah dari relasinya dengan Tuhan.
} 
ciptaan $^{66}$ serta menegaskan kedaulatan, dan keberbedaan Tuhan, dan keintiman relasi Tuhan dengan manusia. Menurut Berkouwer, Alkitab memberikan wahyu tentang manusia hanya dalam hubungannya dengan Tuhan. Hal ini berarti Alkitab bukanlah memberikan penjelasan ontologis tentang manusia yang mandiri terlepas dari relasinya dengan Tuhan. Berkouwer mengatakan,

If we emphasize the person so much that we destroy the unity of reality and devaluate the non-human world in one way or another, we misunderstand the bonds uniting man and the whole creation and misunderstand the meaning of his humanness, and so open the way to our alienation from which God called good. ${ }^{67}$

Dalam berhadapan dengan topik-topik antropologis, Berkouwer selalu kembali kepada dasar pemikirannya mengenai relasi manusia dengan Tuhan yang menjadi keutuhan manusia. Hasil dari pemikiran mengenai relasi manusia dengan Tuhan yang menjadi keutuhan manusia ini membuat Berkouwer menolak usaha-usaha mengidentifikasikan esensi manusia secara mandiri sebagai karakteristik natur manusia. Menurut Berkouwer usaha-usaha antropologis seperti ini akan menjadi dualisme antropologis. ${ }^{68}$ Misalnya, akal budi sebagai karakteristik natur manusia yang esensial, kebebasan manusia sebagai esensi dari natur manusia. Bagi Berkouwer,

Such definitions are actually contrary to what we call the biblical view of man, since they make no mention of what Scripture presents as the essential and unique characteristic of man and man's nature - the relation to God. ${ }^{69}$

Lalu Berkouwer melanjutkan dengan mengatakan bahwa relasi manusia dengan Tuhan bersifat esensi dan konstitutif, bukan sekedar ditambahkan. ${ }^{70}$ Alkitab berbicara tentang manusia hanya dalam hubungannya dengan Tuhan. Relasi manusia dengan Tuhan bukanlah sesuatu yang ditambahkan setelah pembahasan mengenai karakteristik kemanusiaan secara mandiri. Mengidentifikasikan karakteristik manusia secara mandiri tanpa relasinya dengan Tuhan akan menghasilkan pandangan-pandangan yang semakin jauh dari Alkitab. Karena sudut pandang inilah Berkouwer tidak menyetujui adanya analisa mandiri terhadap manusia tentang komponen dan struktur manusia itu sendiri. ${ }^{71}$

66 Ibid., chapter 9.

67 Ibid., 359-360.

68 Ibid., 203.

69 Ibid., 34.

70 Ibid., 22.

71 Berkouwer, Man: The Image of God, 195. 
Konsistensi pemikiran Berkouwer mengenai relasi manusia dengan Tuhan yang tidak dapat dilepaskan dari karakteristik kemanusiaan terlihat dalam pemikirannya mengenai ordo dan norma-norma yang bersifat bawaan. Berkouwer mengatakan bahwa manusia diciptakan di dalam ordo dan norma-norma yang bersifat bawaan. ${ }^{72}$ Dalam pemikirannya mengenai ordo, Berkouwer menafsirkan perkataan Paulus dalam Kitab Roma pasal 2. Ayat tersebut mengatakan bahwa orang kafir menyadari adanya norma-norma di dunia. Walaupun orang kafir ini tidak mengenal Pemberi norma-norma tersebut mereka menghidupi dan membatasi diri mereka dengan norma-norma itu yang berarti mendemonstrasikan supremasi norma-norma ilahi. ${ }^{73}$ Berkouwer mengatakan bahwa Tuhan adalah Pencipta norma-norma tersebut. Mengenai ordo dan norma-norma yang bersifat bawaan, Berkouwer merujuk kepada hukum Tuhan dan Tuhan sebagai Pencipta dan Tuan atas hukum ini, Pemberi hukum ini. ${ }^{74}$ Terhadap norma-norma yang bersifat bawaan tersebut, manusia harus bertanggung jawab kepada Pemberi hukum. ${ }^{75}$ Berkouwer juga mengatakan akan adanya norma-norma ilahi atau hukum-hukum untuk sejarah. Contohnya manusia memiliki kecenderungan untuk membentuk kebudayaan. ${ }^{76}$ Penekanan akan aturan dan norma-norma ini menyatakan manusia yang tidak dapat dijelaskan secara ontologis terlepas dari Penciptanya. Manusia selalu dalam kondisi berrelasi dengan Penciptanya. Segala usaha-usaha eksistensialisme untuk menggambarkan esensi manusia terlepas dari relasi dengan Penciptanya justru menjadi kesaksian akan adanya pewahyuan umum. ${ }^{77}$ Berkouwer menghubungkan pemikirannya mengenai ordo dan norma-norma yang bersifat bawaan ini dengan sensus divinitatis dimana tidak ada manusia yang dapat terhindar dari kuasa Tuhan. ${ }^{78}$

Karena itulah Berkouwer tidak setuju dengan pandangan yang menjadikan kebebasan manusia sebagai esensi dari natur manusia. Sedangkan polemik yang terjadi antara pandangan otonomi dan heteronomi menjadi suatu analisa antropologi dengan usaha-usaha penjelasan mengenai esensi manusia secara ontologis dan terlepas dari relasinya dengan Tuhan. Menurut Berkouwer pembahasan seperti ini akan menjadi penentuan nasib sendiri dan tidak alkitabiah. ${ }^{79}$ Konsep kebebasan seperti ini adalah konsep

72 Berkouwer, General Revelation, 158, 162, 164, 168, 170-171.

Ibid., 185.

Ibid., 200-205.

Ibid., 187. Cf. Sin, chapters 1, 4, 8.

G. C. Berkouwer, The Providence of God (Grand Rapids: Eerdmans, 1952), 168-169.

Berkouwer, Man: The Image of God, 23f. cf. General Revelation, 220-221, 328-329f.

Berkouwer, General Revelation, 151-152, 166f.

79 Penentuan nasib sendiri yang dimaksud adalah menentukan hukum-hukumnya sendiri, tanpa ada tekanan norma-norma dari luar. 
yang melihat kebebasan sebagai esensi manusia dan bukan relasi dengan Pencipta sebagai esensi manusia. Pendekatan akan kebebasan seperti ini telah bergeser dari pengertian akan kebebasan yang diperkenalkan oleh Alkitab dan akan menimbulkan sejumlah masalah pada natur dan arti kebebasan dan batasan-batasannya. ${ }^{80}$ Dengan konsep kebebasan yang tidak alkitabiah ini akan muncul masalah diantara manusia. Manusia akan melawan sesamanya yang membatasi dirinya sendiri dan yang mengancamnya. Berkouwer mengatakan bahwa kebebasan ini sebenarnya hanyalah keinginan akan pelanggaran hukum-hukum yang ada. ${ }^{81}$ Lalu Berkouwer melanjutkan dengan mengatakan bahwa sebaliknya konsep kebebasan ini adalah suatu bentuk perbudakan dan bukanlah kebebasan yang diperkenalkan oleh Alkitab. "Mereka menjanjikan kemerdekaan kepada orang lain, padahal mereka sendiri adalah hamba-hamba kebinasaan, karena siapa yang dikalahkan orang, ia adalah hamba orang itu." (2 Petrus 2:19) menyatakan bahwa terminologi kebebasan yang diserukan oleh pandangan otonomi justru menjadi perbudakan. ${ }^{82}$

Berkouwer menjelaskan bahwa lawan dari kebebasan yang menjadi polemik antara pandangan otonomi dan pandangan heteronomi adalah kebebasan yang tertulis dalam Alkitab. Kebebasan yang alkitabiah adalah kebebasan yang ada di dalam Kristus yang akan disempurnakan secara eskatologis. Kebebasan ini akan terus meningkat hingga orang-orang percaya dimuliakan. Kondisi bebas yang sejati ini tidak memutuskan ikatan manusia dengan sesamanya melainkan melindungi manusia dan memulihkan ikatan-ikatan yang ada.

\section{Kesimpulan}

Pembahasan mengenai kebebasan manusia telah mengalami pergeseran makna. Pembahasan mengenai kebebasan manusia bukan lagi mengenai keadaan manusia yang bebas, keadaan yang tidak terikat oleh kuasa yang menekan. Pembahasan mengenai kebebasan manusia telah bergeser menjadi pembahasan mengenai kehendak bebas. Pandangan otonomi menyatakan bahwa manusia memiliki kebebasan dalam menentukan jalannya sendiri. Pandangan ini menjadikan manusia absolut sehingga dapat menentukan jalannya sendiri tanpa tekanan dari kuasa manapun. Tetapi pandangan heteronomi menyatakan bahwa manusia tidak bebas secara otonom. Adanya otoritas-otoritas eksternal seperti alam, keterbatasan jasmani, keadaan, hukum, dan lainnya, membatasi manusia dalam melakukan tindakannya.

\footnotetext{
Berkouwer, Man: The Image of God, 326.

Ibid., 331.

Ibid., 330-331.
} 
Seperti dikatakan oleh Arthur Schopenhauer, jika orang menganggap kebebasan sebagai "aku dapat melakukan yang kuingini" maka orang ini juga perlu mempertanyakan "apakah aku dapat dengan bebas memilih apa yang aku ingin untuk ingini?" 83 Bahkan ketika semua otoritas eksternal itu dihilangkan pun, masih ada otoritas-otoritas internal yang menekan manusia dalam menentukan jalannya. Otoritas-otoritas internal itu dapat berupa tradisi dan kebutuhan yang mempengaruhi dalam penentuan kehendak. Perbedaan antara pandangan otonomi dan heteronomi menjadi polemik. Polemik antara pandangan otonomi dan heteronomi adalah pembahasan mengenai kehendak bebas yang telah disempitkan ke dalam pengertian kebebasan kehendak ketika diperhadapkan kepada suatu pilihan. Pembahasan ini bukan lagi mengenai kebebasan manusia secara umum dan utuh.

Berkouwer melihat bahwa kehendak bebas hanyalah bagian kecil dari diskusi mengenai kebebasan manusia. Kehendak bebas bukanlah kebebasan manusia itu sendiri. Menurut Berkouwer, segala pandangan heteronomi yang berusaha menjawab pandangan otonomi sebagai kebebasan mutlak manusia dengan berdasarkan pada sekedar pertanyaan-pertanyaan seputar manusia akan semakin jauh dari akar pengertian kebebasan manusia yang ada di dalam Kitab Suci. Yang dibutuhkan dalam perkembangan diskusidiskusi tentang kebebasan manusia ini adalah melihat kembali bagaimana Kitab Suci mengatakan tentang kebebasan, apa yang Tuhan sendiri katakan mengenai kebebasan. Karena dengan menelusuri pengertian kebebasan yang alkitabiah, akan menghindari terjebak dalam pembahasan dilema antara pandangan otonomi dan pandangan heteronomi.

Pandangan Berkouwer mengenai kebebasan manusia tidak memihak baik kepada pandangan otonomi maupun pandangan heteronomi karena ia menganggap kedua pilihan ini berpangkal kepada anggapan-anggapan yang keliru tentang kebebasan dan hakikat manusia. Kebebasan yang diperkenalkan oleh Berkouwer adalah kebebasan yang dinyatakan dalam Alkitab yang merupakan kebebasan manusia yang seutuhnya. Kebebasan sebagai kenyataan dan bukan kemungkinan. Hal ini bukan sekedar masalah kehendak yang bebas karena realita peristiwa Kejatuhan yang membuat manusia kehilangan kebebasannya bahkan dalam kehendaknya. Sebab setelah peristiwa Kejatuhan, manusia memiliki kehendak yang diperbudak oleh dosa (servum arbitrium). Kebebasan sebagai otonomi, penentuan nasib sendiri bukanlah esensi dari manusia. Kebebasan sejati adalah ketaatan penuh, ketaatan terhadap perintah Tuhan. Kenyataan bahwa orang

83 Arthur Schopenhauer, Essay on the Freedom of the Will (Indianapolis: Bobbs-Merrill, 1960), 6. 
percaya bukan lagi dirinya sendiri tidak menghilangkan kebebasan manusia tapi justru menyatakannya sebagai realita yang menyenangkan. Di sinilah kebebasan dinyatakan penuh karena status orang percaya dipulihkan dan dibebaskan dari delusi akan otonominya. 